\title{
Informasi Surat Masuk Dan Surat Keluar Berbasis Web Pada Suatu Instansi
}

\author{
Ahmad Nouvel', Sutrisno ${ }^{2}$, Rizkika Indriani ${ }^{3}$ \\ 1,2,3Universitas Bina Sarana Informatika \\ Email:1ahmad.avl@bsi.ac.id , 2emailsutrisno.stz@bsi.ac.id \\ 3rizkikaindri98@gmail.com
}

\begin{abstract}
Abstrak
Perkembangan global ilmu pengetahuan dan tekhnologi informasi sangat cepat sekali buat peradaban umat manusia, banyak jumlah surat masuk dan surat keluar di suatu instansi, sehingga ketika sistem ini dibuat diharapkan dapat membantu kinerja yang berkaitan dengan surat-menyurat. Di saat ini, mekanisme yang diterapkan pada manajemen surat masuk dan surat keluar pada suatu instansi mulai dari penerimaan, pembuatan, penyimpanan, pendokumentasian surat semua dilakukan secara konvensional, dengan adanya sistem informasi surat masuk dan surat keluar berbasis web ini, sehingga bisa mengurangi kesulitan dalam penyimpanan dan pencarian file surat. Waktu yang dihabiskan buat proses pencarian datadata surat lebih cepat, dan memperbaiki manajemen dari pengarsipan surat yang telah ada. Sistem informasi surat ini memakai metode pengembangan aplikasi menggunakan model waterfall. Pembuatan sistem perangkat lunak ini memakai Atom text editor dan database yang tersimpan di MySQL. Yang dihasilkan dari penelitian ini adalah menghasilkan sistem informasi yang mengelola surat masuk serta surat keluar sesuai alur yang di tetapkan, dan dapat menuntaskan problem saat ini.
\end{abstract}

Kata Kunci: Sistem Informasi, Surat Menyurat, Waterfall

\begin{abstract}
The global development of science and information technology is very fast for human civilization, there is a large number of incoming and outgoing letters in an agency, so that when this system is created it is hoped that it can help performance related to correspondence. At this time, the mechanisms that are applied to the management of incoming and outgoing mail in an agency starting from receiving, making, storing, documenting letters are all done conventionally, with this web-based information system for incoming and outgoing mail, so that it can reduce difficulties in mail file storage and search. Time is spent making the process of retrieving mail data faster, and improving the management of existing mail archives. This letter information system uses the application development method using the waterfall model. The making of this software system uses an Atom text editor and a database stored in MYSQL. The result of this research is to produce an information system that manages incoming and outgoing mail according to a defined flow, and can solve current problems.
\end{abstract}

Keywords: Information Systems, Correspondence, waterfalls

\section{PENDAhULUAN}

Permasalahan yang acapkali ada pada lembaga pemerintahan wilayah yaitu sulitnya menemukan balik file surat masuk ataupun surat keluar, sebab penyimpanan dan penataan file yang belum dikelola secara baik dan masih secara manual. Begitupula dengan penyimpanan file surat masuk ataupun surat keluar pada tempat kerja Pemerintahan wilayah yang masih secara manual akibatnya sulit menemukan kembali arsip buat proses aktivitas. sebagai akibatnya pada saat ini diperlukan suatu sistem pengarsipan surat yang bisa menyimpan data surat masuk dan keluar secara rinci dan sewaktu-waktu bisa mecari surat secara cepat. "Sistem informasi adalah suatu sistem didalam sistem organisasi yang mempertemukan kebutuhan pengolahan transaksi harian, mendukung operasi, bersifat manajerial, dan kegiatan strategi dari organisasi dan menyediakan pihak luar tertentu dengan laporan-laporan yang dibutuhkan"(Hutahaean, 2015). Mengingat begitu pentingnya pengarsipan surat bagi kehidupan berorganisasi, maka keberadaan 
file di sebuah organiasi benar-benar bisa mendukung keberlangsungan aktivitas organisasi. Dalam penelitian ini terdapat beberapa penelitian sebelumnya dari jurnal yang ada sebagai pembanding ataupun acuan dalam pelaksanaan penelitian ini, pada Rancang Bangun Sistem Pengelolaan Arsip Surat Berbasis Web Menggunakan Metode Waterfall sistem pengarsipan surat yang sedang berjalan pada Kantor Desa Karangrau saat ini belum berjalan dengan baik sehingga membutuhkan sistem berbasis computer untuk mengatasinya. Dengan menggunakan sistem informasi arsip surat berbasis web akan mempermudah proses pencarian arsip surat dengan akurat, cepat dan efesien. Sistem yang dihasilkan dapat mendokumentasikan surat masuk dan surat keluar hingga memudahkan pengaksesannya pada saat diperlukan (Suryadi \& Zulaikhah, 2019). Pada Penelitian Sistem Administrasi Pengelolaan Arsip Surat Masuk Dan Surat Keluar Dengan adanya sistem administrasi pengelolaan arsip surat masuk dan surat keluar berbasis website dapat mempermudah bagi pegawai dalam mengelola arsip surat dari tahun ke tahun dengan mudah dan terhendar dari kerusakan arsip. Adanya sistem administrasi pengelolaan surat masuk dan surat keluar berbasis mempermudah dalam hal pencarian arsip surat dengan akurat, mudah dan efisien (Masykur et al., 2015).

Aktivitas pengarsipan surat sangatlah krusial dalan suatu instansi. Surat ialah salah satu wahana krusial pada suatu instansi sebab banyak informasi krusial yang terkandung didalamnya, sebagai akibatnya di perlukan penarsipan surat yang baik. Jika surat-surat telah di proses selanjutnya surat wajib di simpan secara baik karena surat sudah menjadi arsip dan sewaktu-waktu bisa di pertanyakan ketika laporan pengarsipan surat. Info pada bentuk data digital berupa teks, gambar, video, audio, serta animasi yang terdapat di sekumpulan laman serta bisa disediakan melalui jalur internet disebut website(Abdullah, 2016). Penulis membuat sistim informasi surat menyurat menggunakan model waterfall, sehingga kegiatan surat menyurat dapat berjalan lancar.

\section{METODE PENELITIAN}

1. Metode Pengembangan Perangkat Lunak

Metode yang digunakan pada pengembangan software ini

menggunakan model waterfall. Model SDLC (system development life cycle) air terjun (waterfall) sering pula disebut model sekuensial linier (sequential linear) atau alur hidup klasik (classic life cycle)(Sukamto, Rosa Ariani, 2016). Ada 4 tahap yang penulis gunakan dalam model waterfall, yaitu:

a. Analisa Kebutuhan Perangkat Lunak

Pada termin ini penulis menganalisa dokumen yang ada lalu menemukan persoalan yang terjadi pada sistem serta menghasilkan solusi buat pemecahan problem sistem yang masih manual buat pengarsipan surat, dengan adanya sistem ini akan memudahkan pada pencarian dan penyimpanan surat.

b. Desain

Dasar untuk menciptakan desain adalah berdasarkan hasil Analisa kebutuhan perangkat lunak. Desain yang penulis hasilkan pada termin ini adalah entity relationship diagram (ERD), logical record structure(LRS), dan rancangan antar muka website.

c. Pengkodean

d. Pengujian

2. Teknik Pengumpulan Data

Teknik yang digunakan untuk pengumpulan data sebagai berikut:

a. Wawancara

Penulis melakukan wawancara menggunakan cara Tanya jawab secara langsung kepada

narasumber atau pegawai yang menangani bagian pengarsipan surat. Penulis juga ikut langsung membantu pengarsipan yang sedang berjalan disana.

b. Pengamatan

Penulis melakukan Observasi dilakukan pada tempat bagian yang menangani pengarsipan surat masuk serta surat keluar, dengan tiba langsung serta mengamati proses pengarsipan surat masuk dan surat keluar yang terdapat pada tempat kerja tersebut.

c. Studi Pustaka

Studi pustaka dilakukan buat melengkapi data yang di perlukan menggunakan cara membaca,mencari dan mengkaji buku,jurnal atau keterangan berdasarkan internet yang sesuai dengan pembahasan materi sebagai pembanding dalam menuntaskan penulisan ini. 


\section{HASIL DAN PEMBAHASAN}

1. Entity Relationship Digram (ERD)

Adapun Entity Relationship Diagram (ERD) yang digunakan pada sistem Informasi Surat Masuk Dan Surat Keluar Berbasis Web Pada Suatu Instansi sebagai berikut:

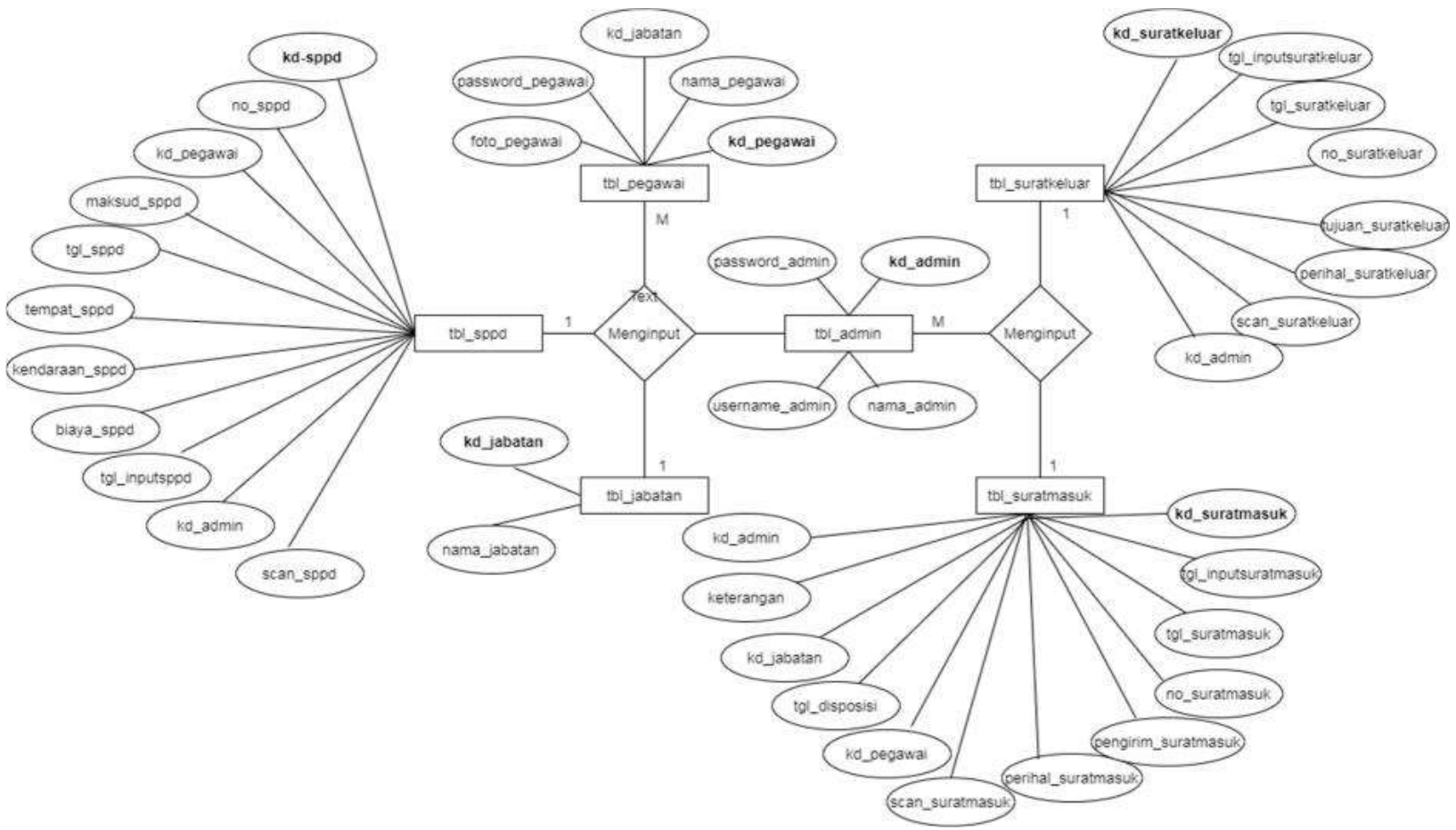

Gambar 1. Entity Relationship Diagram (ERD)

\section{Logical Record Structure (LRS)}

LRS merupakan suatu bentuk relational model yang dibuat secara logic atau external level dan terkonsep sebelum tabel terbentuk dari field atau atribut entitas secara fisik atau internal level. Logical Record Structures juga merupakan hasil dari pemodelan Entity Relationship (ER) beserta atributnya yang saling terhubung dengan entitas(Supriyanta, 2017)

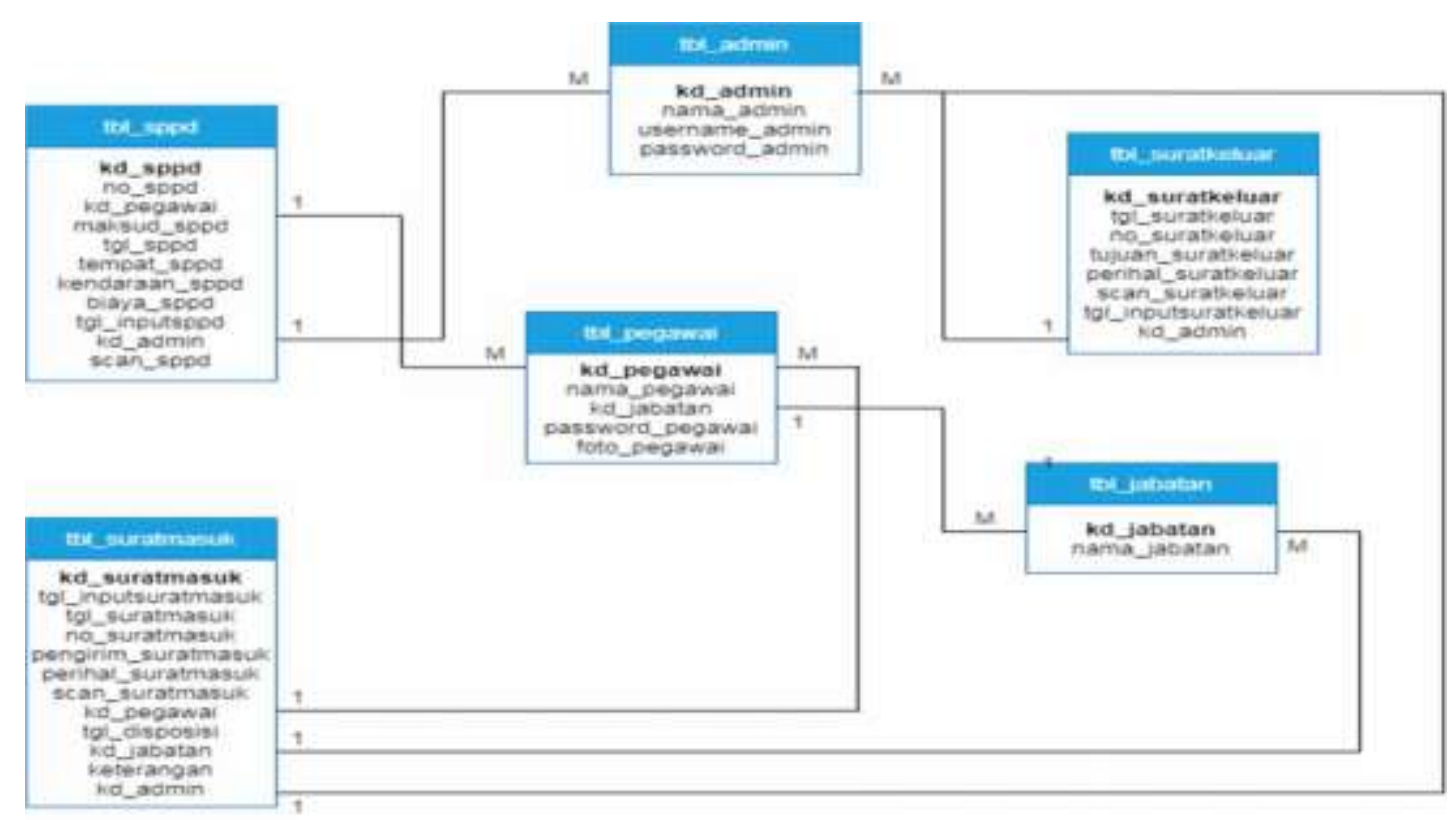

Gambar 2. Logical Record Structure (LRS) 


\section{Spesifikasi File}
a) File Admin
b) File Jabatan
c) File Judul
d) File Pegawai
e) File Surat Masuk
f) File Surat Keluar

\section{Pengkodean}
a) Kode Jabatan
b) Kode Pegawai
c) Kode Surat Masuk
d) Kode Surat Keluar

\section{Spesifikasi Program}
a) Struktur Navigasi Admin
b) Struktur Navigasi Pegawai

\section{Spesifikasi Sistem Komputer}

1. Spesifikasi Hardware:

Procesor : Intel ${ }^{\circledR}$ Atom ${ }^{\mathrm{TM}} \mathrm{CPU} \mathrm{N} 4501.66 \mathrm{GHz} 1.67 \mathrm{GHz}$

RAM : RAM 4GB

Harddisk : Harddisk 500GB

Mouse : Optical Mouse

Keyboard : Standart Keyboard

Monitor : Monitor dengan resolusi layar minimum 14 inch

Printer : Inkjet dan Laser

Koneksi :Koneksi internet dengan kecepatan minimal 2Mbps

2. Spesifikasi Software:

Sistem operasi : Microsoft Windows 7.

Bahasa Pemrograman : Atom.

Browser : Google Chrome.

Program atau software pendukung : Xampp V3.2.1, MySQL

\section{Implementasi}

7.1. Implementasi Rancangan Antar Muka Admin

1) Halaman Utama Admin

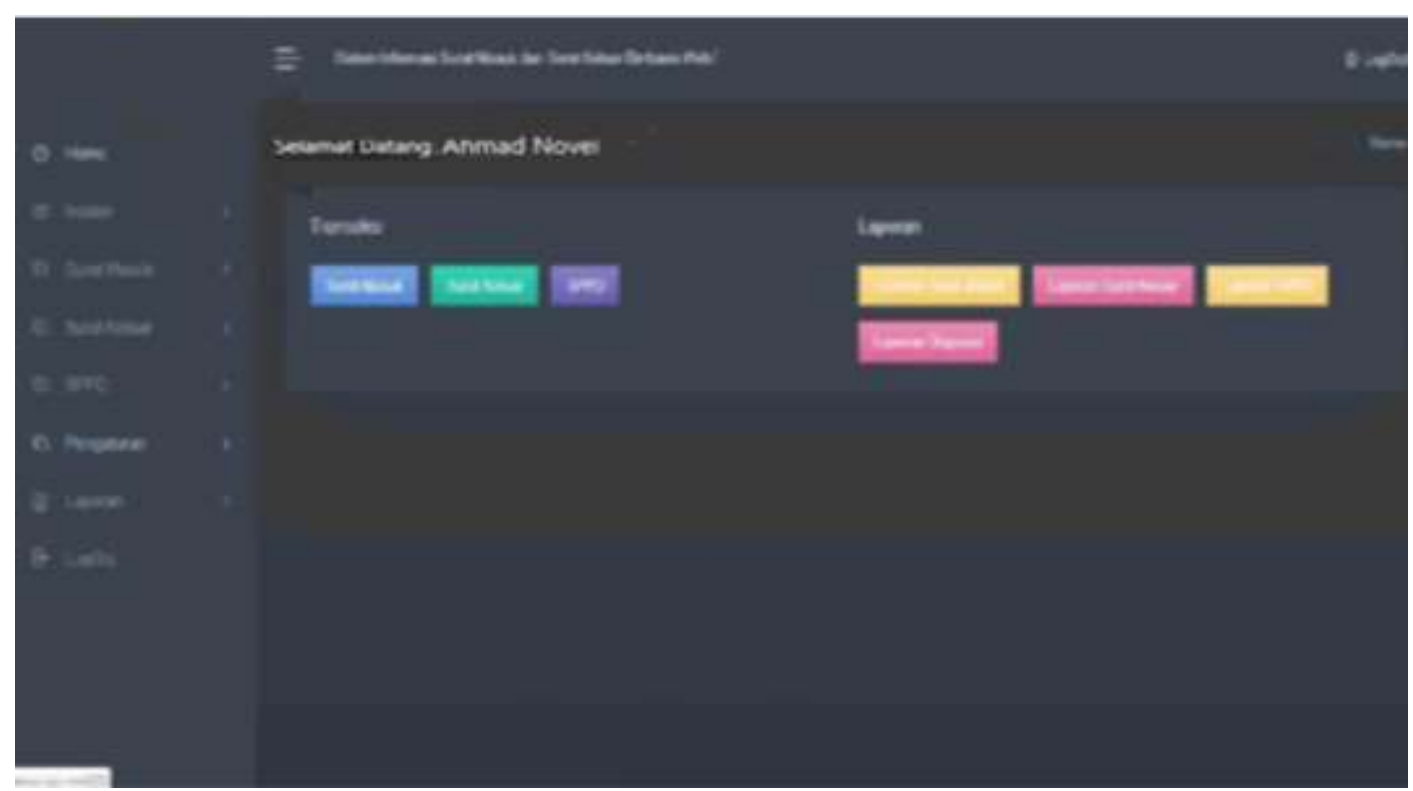

Gambar 3. Halaman Utama Admin 
Indonesian Journal on Software Engineering (IJSE)

Vol. 7, No. 1, Juni 2021, hlm. 55-62

p-ISSN: 2461-0690

Akreditasi KEMENRISTEKDIKTI, No. 85/M/KPT/2020

e-ISSN: 2714-9935

2) Halaman input Surat Masuk

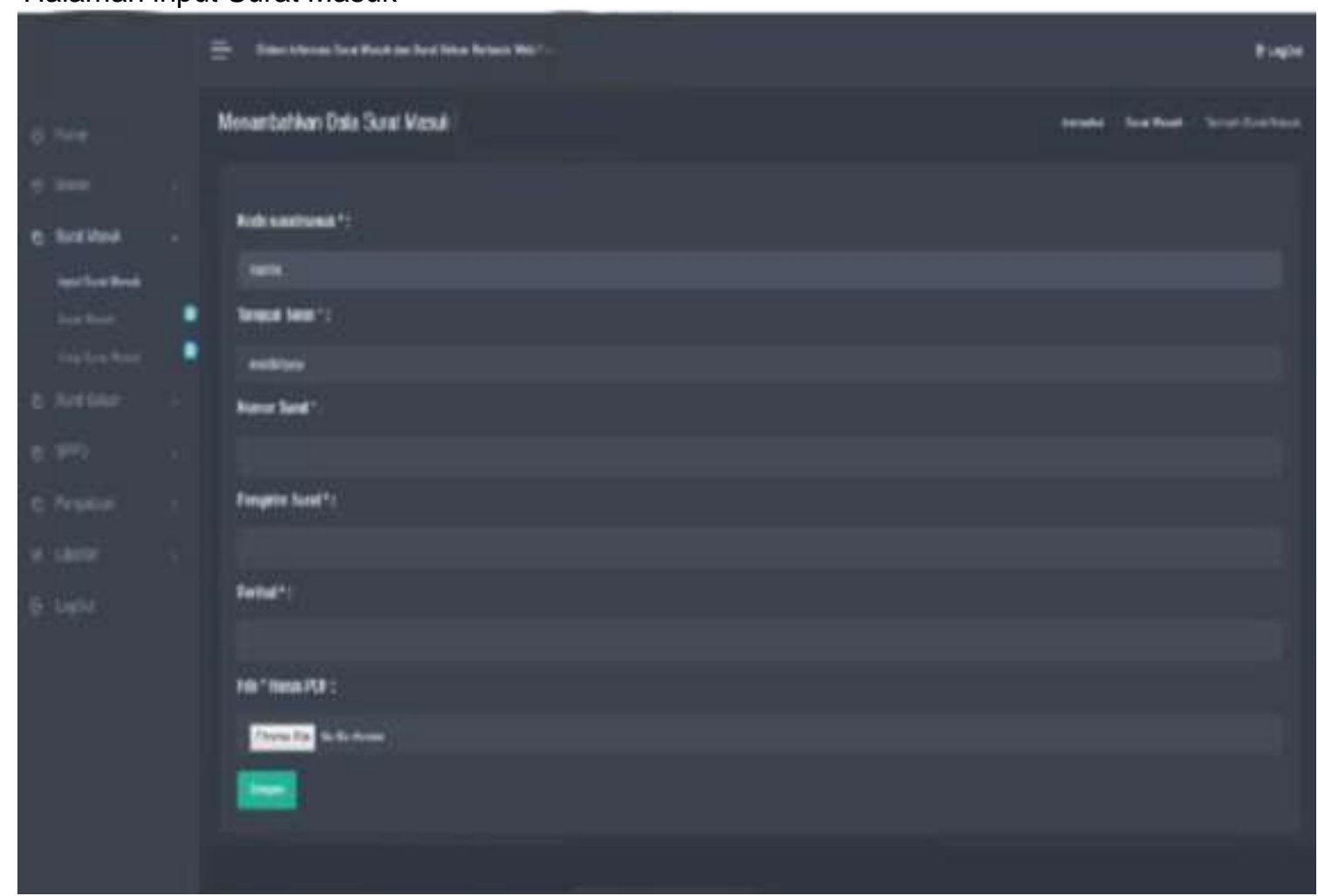

Gambar 4. Halaman Input Surat Masuk

7.2. Implementasi Rancangan Halaman Kepala Desa

1) Halaman Utama Kepala Desa

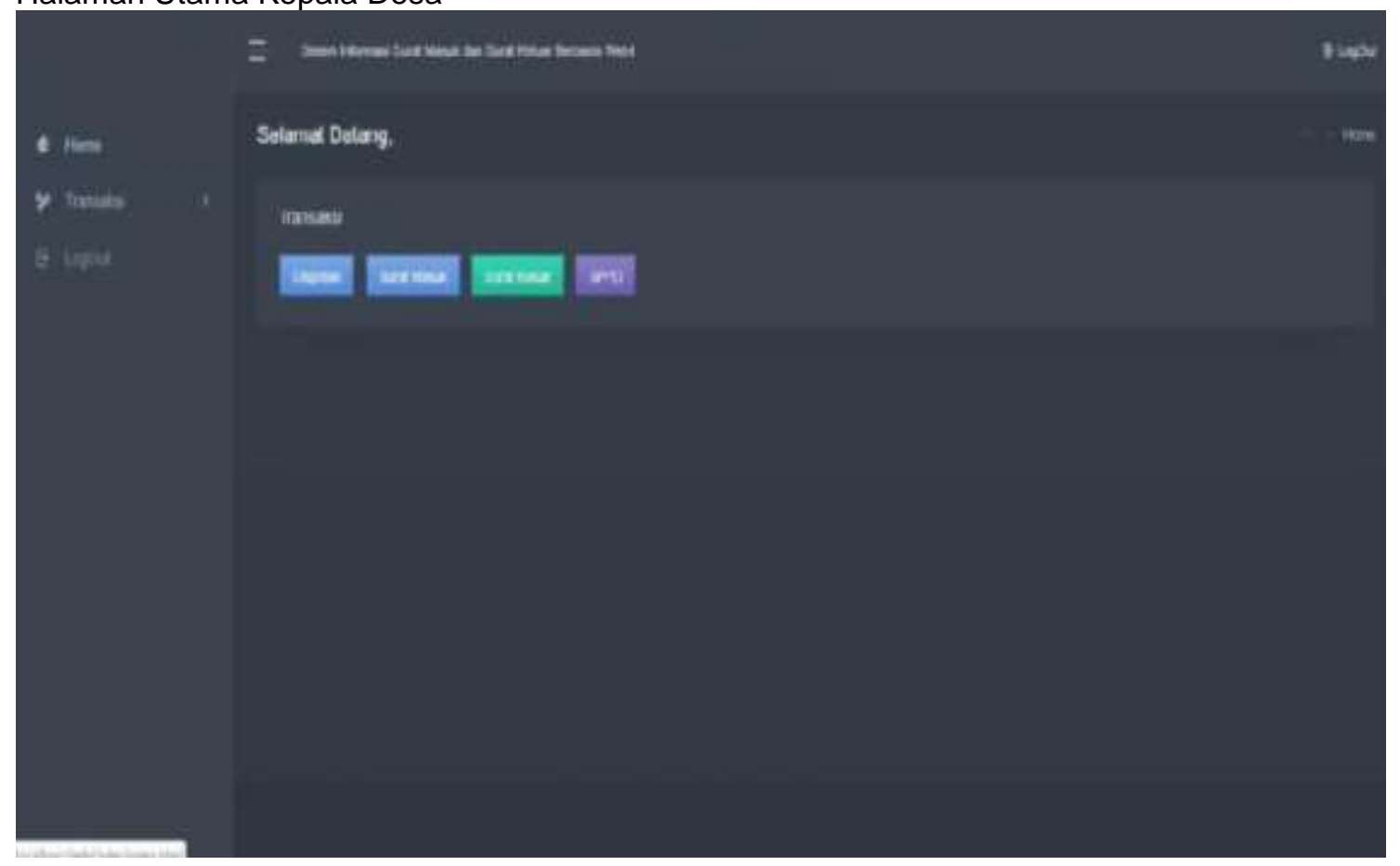

Gambar 5. Halaman Utama Kepala Desa 
Indonesian Journal on Software Engineering (IJSE)

Vol. 7, No. 1, Juni 2021, hlm. 55-62

p-ISSN: 2461-0690

Akreditasi KEMENRISTEKDIKTI, No. 85/M/KPT/2020

e-ISSN: 2714-9935

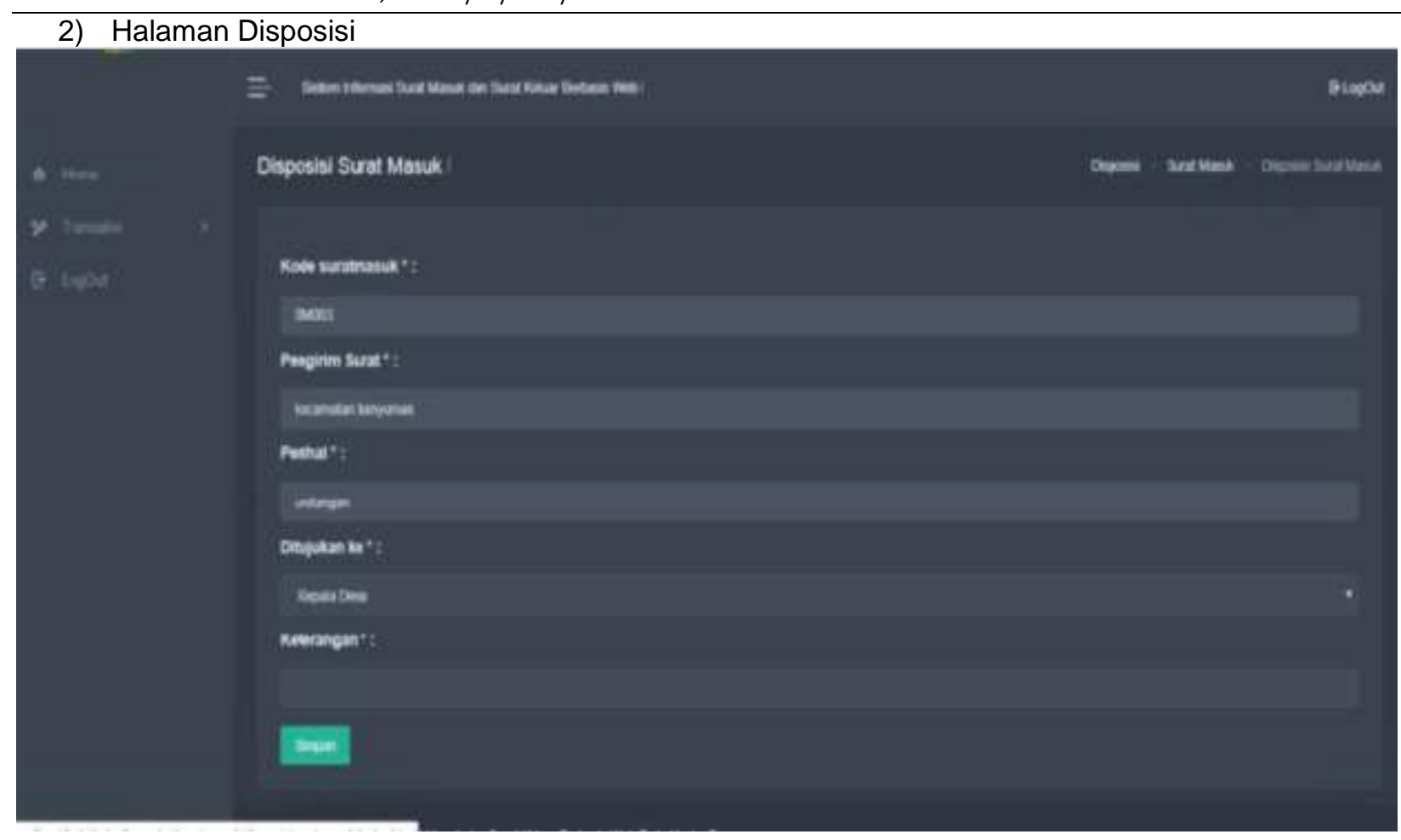

3) Halaman arsip surat masuk

Gambar 6. Halaman Disposisi

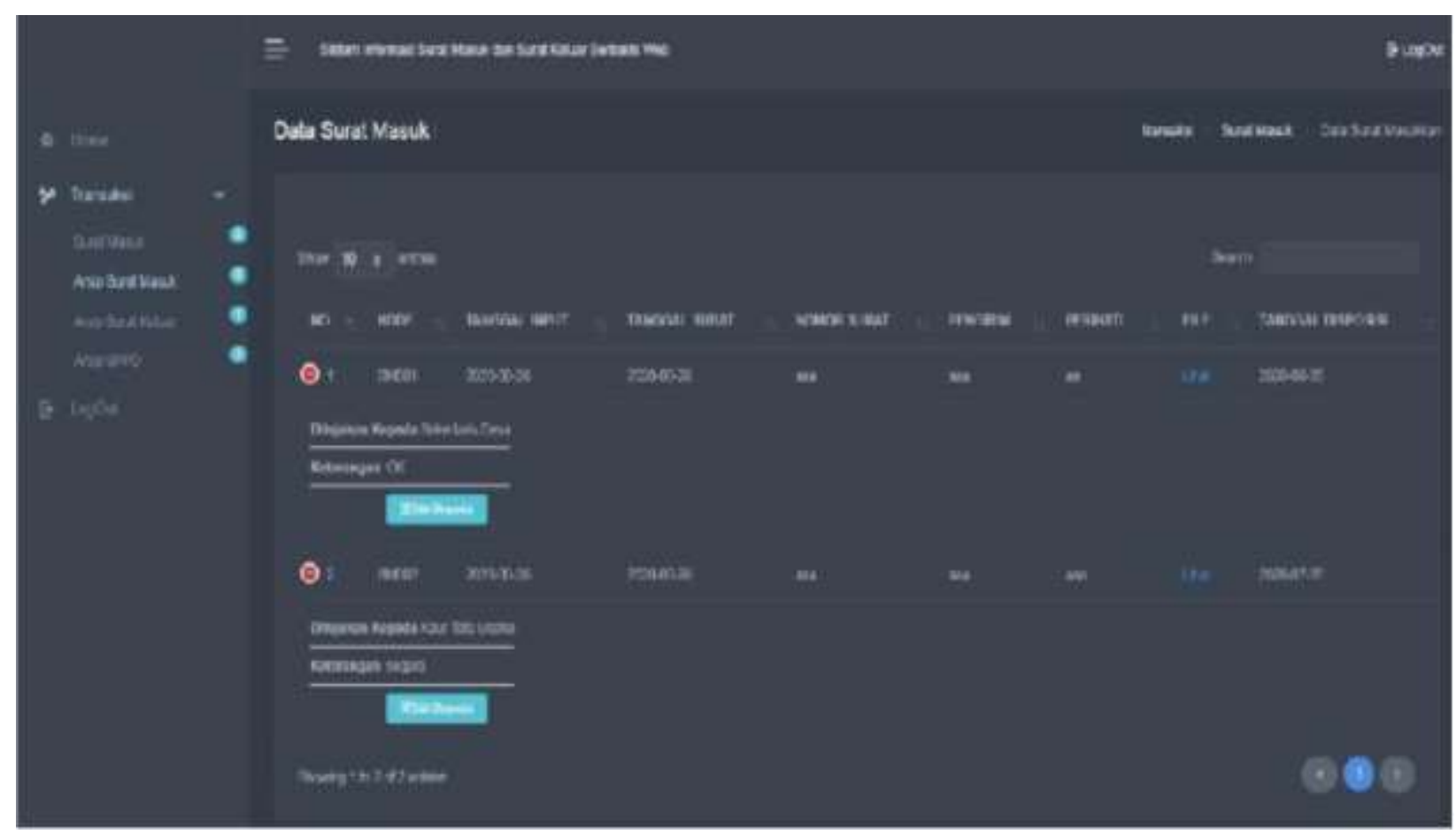

Gambar 7. Halaman arsip surat masuk

\section{Pengujian Unit}

Pengujian software berasal dari segi fungsional tanpa menguji desain serta kode program buat mengetahui tidak terjadinya error serta fungsi masukan serta keluaran dari perangkat lunak sesuai dengan spesifikasi yang diharapkan disebut dengan Black Box-Testing(Sukamto, Rosa Ariani, 2016). 


\begin{tabular}{|c|c|c|c|c|c|}
\hline \multicolumn{6}{|c|}{ Tabel 1. Hasil Pengujian Blackbox Testing Form Input Surat Masuk } \\
\hline No & $\begin{array}{c}\text { Skenario } \\
\text { Pengujia } \\
\text { n }\end{array}$ & Text case & Hasil yang diharapkan & $\begin{array}{c}\text { Hasil } \\
\text { pengujian }\end{array}$ & $\begin{array}{l}\text { Kesimpula } \\
\mathrm{n}\end{array}$ \\
\hline 1 & $\begin{array}{l}\text { Semua } \\
\text { data diisi } \\
\text { kecuali } \\
\text { Tanggal } \\
\text { Surat } \\
\text { kemudian } \\
\text { klik } \\
\text { tombol } \\
\text { "Simpan" }\end{array}$ & $\begin{array}{l}\text { Kode suratmasuk:SM001 Tan } \\
\text { ggal surat :(kosong) Nomer } \\
\text { surat } 111 / \text { bms/und Pengirim } \\
\text { surat: kecamatan banyumas } \\
\text { Perihal : undanganFile: } \\
\text { surat.pdf }\end{array}$ & $\begin{array}{l}\text { Sistem akan menolak } \\
\text { datasurat masuk } \\
\text { dan menampilkan“Masukan } \\
\text { Tanggal surat" }\end{array}$ & $\begin{array}{l}\text { Sesuai harap } \\
\text { an }\end{array}$ & Valid \\
\hline 2 & $\begin{array}{l}\text { Semua } \\
\text { data diisi } \\
\text { kecuali } \\
\text { Nomor } \\
\text { Surat } \\
\text { kemudian } \\
\text { klik } \\
\text { tombol } \\
\text { "Simpan" }\end{array}$ & $\begin{array}{l}\text { Kode suratmasuk:SM001 Ta } \\
\text { nggal surat : 4- 11-2020 } \\
\text { Nomer surat: } \\
\text { (kosong) Pengirim surat: } \\
\text { kecamatan banyumas Perihal } \\
\text { : undanganFile: surat.pdf }\end{array}$ & $\begin{array}{l}\text { Sistem akan menolak } \\
\text { datasurat masuk } \\
\text { dan menampilkan“Masukan } \\
\text { Nomer surat" }\end{array}$ & $\begin{array}{l}\text { Sesuai harap } \\
\text { an }\end{array}$ & Valid \\
\hline 3 & $\begin{array}{l}\text { Semua } \\
\text { data diisi } \\
\text { kecuali } \\
\text { Pengirim } \\
\text { Surat } \\
\text { kemudian } \\
\text { klik } \\
\text { tombol } \\
\text { "Simpan" }\end{array}$ & $\begin{array}{l}\text { Kode } \\
\text { suratmasuk:SM001 Tanggal } \\
\text { surat :4-7- } 2020 \text { Nomer surat } \\
: 111 / \text { bms/und Pengirim surat: } \\
\text { (kosong) Perihal : } \\
\text { undanganFile: surat.pdf }\end{array}$ & $\begin{array}{l}\text { Sistem akan menolak } \\
\text { datasurat } \\
\text { masuk dan menampilkan } \\
\text { "Masukan Pengirim surat" }\end{array}$ & $\begin{array}{l}\text { Sesuai harap } \\
\text { an }\end{array}$ & Valid \\
\hline 4 & $\begin{array}{l}\text { Semua } \\
\text { data diisi } \\
\text { kecuali } \\
\text { Perihal } \\
\text { kemudian } \\
\text { klik } \\
\text { tombol } \\
\text { "Simpan" }\end{array}$ & $\begin{array}{l}\text { Kode suratmasuk:SM001 } \\
\text { Tanggal surat :4- } \\
7-2020 \text { Nomer surat } \\
: 111 / \text { bms/und }\end{array}$ & $\begin{array}{l}\text { Sistem akan menolak atasurat } \\
\text { masuk dan menampilkan"Mas } \\
\text { ukan }\end{array}$ & $\begin{array}{l}\text { Sesuai harap } \\
\text { an }\end{array}$ & Valid \\
\hline 5 & $\begin{array}{l}\text { Semua } \\
\text { data diisi } \\
\text { kecuali } \\
\text { File } \\
\text { kemudian } \\
\text { klik } \\
\text { tombol } \\
\text { "Simpan" }\end{array}$ & $\begin{array}{l}\text { Kode suratmasuk:SM001Tan } \\
\text { ggal surat : 4-7- } 2020 \text { Nomer } \\
\text { surat :111/bms/und Pengirim } \\
\text { surat: kecamatan banyumas } \\
\text { Perihal : undanganFile: } \\
\text { (kosong) }\end{array}$ & $\begin{array}{l}\text { Sistem akan menolak } \\
\text { datasurat } \\
\text { masuk dan menampilkan } \\
\text { "Masukan File surat" }\end{array}$ & $\begin{array}{l}\text { Sesuai harap } \\
\text { an }\end{array}$ & Valid \\
\hline 6 & $\begin{array}{l}\text { Mengetik } \\
\text { an } \\
\text { semuadat } \\
\text { a dengan } \\
\text { datayang } \\
\text { benar } \\
\text { kemudian } \\
\text { klik } \\
\text { tombol } \\
\text { "Simpan" }\end{array}$ & $\begin{array}{l}\text { Kode suratmasuk:SM001 Tan } \\
\text { ggal surat :4-7-2020 Nomer } \\
\text { surat :111/bms/und Pengirim } \\
\text { surat: kecamatan banyumas } \\
\text { Perihal : undanganFile: } \\
\text { surat.pdf }\end{array}$ & $\begin{array}{l}\text { Sistem akanmenerima } \\
\text { datadan } \\
\text { akan menampilkandata surat } \\
\text { masuk }\end{array}$ & $\begin{array}{l}\text { Sesuai harap } \\
\text { an }\end{array}$ & Valid \\
\hline
\end{tabular}




\begin{tabular}{|c|c|c|c|c|c|}
\hline No & $\begin{array}{r}\text { Skenario } \\
\text { Pengujian }\end{array}$ & Text case & $\begin{array}{l}\text { Hasil yang } \\
\text { diharapkan }\end{array}$ & Hasil pengujian & Kesimpulan \\
\hline 1 & $\begin{array}{l}\text { Semua } \\
\text { data diisi } \\
\text { kecuali } \\
\text { Tanggal } \\
\text { Surat } \\
\text { kemudian } \\
\text { klik tombol } \\
\text { "Simpan }\end{array}$ & $\begin{array}{l}\text { Kode Tanggal } \\
\text { surat :(kosong), Nomer surat } \\
: 110 / \text { kdg/und, Tujuan surat : } \\
\text { kecamatan banyumas, Perihal : } \\
\text { undangan, File: surat.pdf }\end{array}$ & $\begin{array}{l}\text { Sistem akan } \\
\text { menolak data } \\
\text { surat masuk dan } \\
\text { menampilkan } \\
\text { "Masukan Tanggal } \\
\text { surat" }\end{array}$ & Sesuai harapan & Valid \\
\hline 2 & $\begin{array}{l}\text { Semua } \\
\text { data diisi } \\
\text { kecuali } \\
\text { Nomor } \\
\text { Surat } \\
\text { kemudian } \\
\text { klik tombol } \\
\text { "Simpan }\end{array}$ & $\begin{array}{l}\text { Kode suratkeluar:SK001, Tanggal } \\
\text { surat :4- 7-2020 Nomer surat } \\
:(\text { kosong) Tujuan surat : } \\
\text { kecamatan banyumas, Perihal : } \\
\text { undanganFile: surat.pdf }\end{array}$ & $\begin{array}{l}\text { Sistem akan } \\
\text { menolak data } \\
\text { surat masuk } \\
\text { dan menampilkan } \\
\text { "Masukan Nomer } \\
\text { surat" }\end{array}$ & Sesuai harapan & Valid \\
\hline 3 & $\begin{array}{l}\text { Semua } \\
\text { data diisi } \\
\text { kecuali } \\
\text { Tujuan } \\
\text { Surat } \\
\text { kemudian } \\
\text { klik tombol } \\
\text { "Simpan" }\end{array}$ & $\begin{array}{l}\text { Kode suratkeluar:SK001, Tanggal } \\
\text { surat :4- 7-2020, Nomer surat } \\
: 110 / \mathrm{kdg} / \text { und, Tujuan surat } \\
:(\text { kosong), Perihal : undanganFile: } \\
\text { surat.pdf }\end{array}$ & $\begin{array}{l}\text { Sistem akan } \\
\text { menolak data } \\
\text { surat masuk } \\
\text { dan menampilkan } \\
\text { "Masukan tujuan } \\
\text { surat" }\end{array}$ & Sesuai harapan & Valid \\
\hline 4 & $\begin{array}{l}\text { Semua } \\
\text { data diisi } \\
\text { kecuali } \\
\text { Perihal } \\
\text { kemudian } \\
\text { klik tombol } \\
\text { "Simpan" }\end{array}$ & $\begin{array}{l}\text { Kode suratkeluar:SK001Tanggal } \\
\text { surat :4- 7-2020 Nomer surat } \\
: 110 / \mathrm{kdg} / \text { und }\end{array}$ & $\begin{array}{l}\text { Sistem akan } \\
\text { menolak data } \\
\text { surat masuk } \\
\text { dan menampilkan } \\
\text { "Masukan Nomer } \\
\text { surat" }\end{array}$ & Sesuai harapan & Valid \\
\hline
\end{tabular}

\section{KESIMPULAN}

Sebagai akhir dari penulisan ini, maka penulis bisa mengambil kesimpulan yang berasal dari pembuatan Sistem surat masuk dan surat keluar di suatu instansi antara lain Menghemat waktu dalam pencarian surat masuk dan surat keluar, Menghemat biaya pengiriman karena online. Dengan menggunakan sistem infrormasi surat masuk dan surat keluar berbasis web akan memudahkan pengarsipan surat. Berdasarkan konklusi yang diperoleh,maka penulis menyampaikan beberapa saran yang dibutuhkan agar program sistem informasi surat masuk dan surat keluar berbasis web ini data digunakan secara maksimal. Adapun saran-sarannya diperlukan administrator buat mengelola manajemen website yang bertanggung jawab. Perlu perawatan berkala untuk perangkat keras dan perangkat lunaknya..

\section{REFERENSI}

Abdullah, R. (2016). Easy \& Simple Web Programming. Jakarta: PT Elex Media Komputindo. Hutahaean, J. (2015). Konsep Sistem Informasi. Yogyakarta: Deepublish.

Masykur, F., Makruf, I., \& Atmaja, P. (2015). Sistem Administrasi Pengelolaan Arsip Surat Masuk Dan

Surat Keluar Berbasis Web. Indonesian Journal on Networking and Security, 4(3), 1-7.

Sukamto, Rosa Ariani, M. S. (2016). Rekayasa Perangkat Lunak Terstruktur dan Berorientasi Objek. Bandung: Informatika.

Supriyanta, A. (2017). Perancangan Website Sebagai Media Promosi Dan Penjualan Pada Cv Simba Jaya Magelang. ljns.Org, 6/1, 9-13. http://ijns.org/journal/index.php/ijns/article/view/1443

Suryadi, A., \& Zulaikhah, yuli siti. (2019). Rancang Bangun Sistem Pengelolaan Arsip Surat Berbasis Web Menggunakan Metode Waterfall. Jurnal Khatulistiwa Informatika, 7(1), 13-21. 